\title{
Kajian faktor-faktor yang mempengaruhi niat beli produk organik
}

\author{
Trestina Ekawati ${ }^{*}$ \\ Titik Kusmantini \\ Yekti Utami \\ trestinae@gmail.com \\ Program Studi Manajemen, FEB UPN “Veteran” Yogyakarta
}

\begin{abstract}
The practice of sustainable consumption or consumption of green products has become a global trend. The balance of an increasingly competitive business world and sustainable development with the business cycle (consumption and production of green products) in the context of the triple bottom line must be maintained. Research on green products especially on organic products has become an academic and practitioner focus. This study tries to re-analyze the "Theory of Planned Behavior" (TPB) by examining the influence of attitude components, subjective norms and behavioral control on the purchase intention of green products. This research focuses on consumers of organic products in Sleman, Yogyakarta Special Region. Data collection techniques were carried out by distributing questionnaires to 228 consumers of green products. Hypothesis testing uses SEM (Structural Equation Modeling). Analysis technique based on PLS (Partial Least Square). The results showed that attitudes towards green products, subjective norms, and perceived behavioral control had a positive and significant effect on green product purchase intentions. The results showed that attitudes towards green products became the most dominant component forming green product purchase intentions. The practical implications of the results of this study are to provide input that effective marketing communication needs to be built through promotion and good ecolabeling and product packaging programs.
\end{abstract}

Keywords: purchase intention; theory of planned behavior; sustainable consumption; organic food.

\section{Pendahuluan}

Dari perspektif keberlanjutan, Robin dan Roberts (1998) mengatakan bahwa konsumsi berkelanjutan diartikan sebagai strategi yang berfokus pada cara-cara baru dalam mengelola sisi permintaan ekonomi, tidak hanya berfokus pada manfaat ekonomi tetapi juga menfaat lingkungan maupun sosial. Majalah Forbes melaporkan daftar perusahaan yang paling berkelanjutan dalam Forum Ekonomi Dunia di Davos, Swiss pada bulan Januari 2019 lalu. Daftar tersebut, memberi peringkat pada perusahaan-perusahaan besar di seluruh dunia dalam hal kinerja mereka mengurangi karbon dan limbah, keragaman gender pada pemimpin,

\footnotetext{
${ }^{1}$ Corresponding author: trestinae@gmail.com
} 
pendapatan yang diperoleh dari produk-produk ramah lingkungan dan keberlanjutan secara keseluruhan. Mereka membuat makanan yang dapat dikonsumsi lebih aman. Artinya bahwa dengan menciptakan produk yang ramah lingkungan akan membawa begitu banyak bobot persentase pendapatan dari suatu perusahaan. Ada komitmen yang berkembang terhadap prinsip-prinsip ESG (environmental, social and governance) di dalam tren keberlanjutan di antara perusahaan-perusahaan dan khususnya pada bangunan atau proyek (real estate). Ketertarikan kuat generasi milenial dalam praktik bisnis yang sadar terhadap lingkungan dan sosial adalah faktor utama yang mendorong tren keberlanjutan ini.

Beberapa tahun terakhir, penggunaan bahan-bahan organik yang dikenal sebagai pertanian organik mendapat perhatian lebih dalam industri pertanian di Indonesia (Prasetyaningtyas et al., 2019). Indonesia sebagai salah satu negara berkembang dengan jumlah penduduk sekitar 252 juta per tahun dan pertumbuhan ekonomi 5,2\% per tahun memiliki potensi untuk menjadi salah satu produsen terbesar dan pasar untuk produk organik (David, 2016). Indonesia memiliki 17 juta hektar lahan pertanian kosong yang digunakan untuk lahan organik, sehingga pendapatan ekspor produk organik dari 17 juta hektar tersebut dapat mencapai \$100 per tahun (Hubeis et al., 2013). Namun demikian, mayoritas pertanian organik Indonesia adalah pertanian yang kecil dengan budidaya kurang dari 0,25 hektar, sebagian besar terorganisir secara individu dan kurangnya informasi akses teknologi dan jaringan (Tridjaja, 2016). Beberapa kebijakan telah dibentuk oleh pemerintah untuk mendukung pertanian organik di Indonesia. Pemerintah Indonesia melakukan sebuah program "Go Organic 2010" yang bertujuan untuk meningkatkan kesadaran masyarakat akan manfaat pertanian organik (Nugraheni dan Purnama, 2013).

Meskipun potensi pertanian organik besar dan ada dukungan dari pemerintah, namun kondisi keberlanjutan pertanian organik di Indonesia stagnan. Perkembangan ekonomi pertanian masih minim karena investasi juga sedikit. Investor pertanian dapat menerapkan Good Argriculture Practise, sehingga produk yang dihasilkan seragam kualitasnya. Para investor dapat mempertemukan penawaran dan permintaan. Sistem produksi harus dapat membaca situasi pasar. Konsumen menengah ke atas misalnya, di era saat ini telah bergeser ke arah konsumsi makanan sehat (healthy food) dengan tidak melibatkan zat-zat kimia yang dapat merusak kesehatan dan lingkungan (David, 2016).

Para peneliti di negara maju dan negara berkembang menerapkan model standar Ajzen dan Fishbein's (1980) “Theory of Planned Behavior" (TPB) yang menyusun ukuran sikap, norma subyektif, dan kontrol perilaku yang dirasakan konsumen untuk menggambarkan hubungan sikap dan perilaku konsumen terhadap produk hijau. TPB adalah pengembangan dari "Theory of Reasoned Action" (TRA). Menurut Ajzen, TRA belum dapat menjelaskan tingkah laku yang tidak sepenuhnya berada di bawah kontrol seseorang. Oleh karena itu, dalam TPB ditambahkan satu faktor yaitu kontrol perilaku. Kontrol perilaku merupakan persepsi individu terhadap kontrol yang dimilikinya sehubungan dengan perilaku tertentu (Ajzen, 2005). Perilaku yang dimaksud dalam penelitian ini adalah perilaku konsumen terhadap konsumsi produk hijau. 
TPB telah digunakan sebagai model dalam penelitian khususnya pada perilaku pembelian makanan organik (Paul et al., 2016). Beberapa peneliti menekankan pada kesenjangan (gap) literatur sikap-niat-perilaku konsumsi hijau baik dalam konteks negara maju maupun negara berkembang (Wei et al., 2017).

Literatur perilaku konsumsi hijau masih perlu dikaji ulang karena komponen sikap saja tidak cukup sebagai prediktor perilaku (Ajzen 2001). Konsumen yang memiliki sikap positif terhadap produk berkelanjutan tidak selalu konsisten menunjukkan ke arah niat beli yang pada akhirnya akan berpengaruh pada perilaku pembelian. Komponen norma subyektif dalam penelitian yang dilakukan oleh Sheppard et al., (1988) juga ditemukan sebagai prediktor lemah dalam model TPB. Sementara itu, berbeda dengan penelitian Chen dan Deng (2016) yang menemukan bahwa perilaku konsumsi hijau adalah perilaku yang mengandung unsur moralitas pribadi dan tanggung jawab sosial. Penambahan norma-norma moral pada model asli TPB dapat meningkatkan kekuatan model TPB sendiri dalam memprediksi perilaku pembelian produk hijau. Berdasarkan diskusi di atas, telah dipaparkan berbagai ulasan terhadap kesenjangan ( gap) literatur dalam model kognitif dari TPB. Penelitian ini mencoba untuk menganalisis kembali TPB yaitu dengan menguji pengaruh sikap, norma subyektif dan kontrol perilaku terhadap niat pembelian produk hijau.

\section{Tinjauan Pustaka}

\subsection{Theory of Planned Behavior (TPB)}

TPB (Theory of Planned Behavior) adalah salah satu teori yang banyak digunakan untuk menyelidiki perilaku konsumen dalam pembelian produk hijau. TPB dapat digunakan untuk menjelaskan perilaku manusia dan penentu psikologis (Rahab et al., 2016). TPB merupakan penyempurnaan dari reason action theory. Sama seperti reason action theory, fokus utama dari teori planned behavior adalah niat individu untuk melakukan perilaku tertentu. Reason action theory menyebutkan ada dua faktor penentu niat yaitu sikap pribadi dan norma subyektif (Fishbein dan Ajzen, 1975). Namun, Ajzen berpendapat bahwa reason action theory belum dapat menjelaskan tingkah laku yang tidak sepenuhnya berada di bawah kontrol seseorang. Oleh karena itu, Ajzen menambahkan satu faktor yang menentukan niat yaitu perceived behavioral control. Perceived behavioral control merupakan persepsi individu terhadap kontrol yang dimilikinya sehubungan dengan perilaku tertentu. Ketiga faktor yaitu sikap, norma subjektif, dan perceived behavioral control dapat memprediksi niat individu dalam melakukan perilaku tertentu (Ajzen, 2005).

\subsubsection{Niat Beli (Purchase Intention)}

Niat pembelian produk hijau merujuk pada kesiapan individu untuk melakukan perilaku pembelian produk ramah lingkungan, terutama mencerminkan pertimbangan polusi yang lebih sedikit yang diasumsikan sebagai anteseden langsung dari tingkah laku. Niat beli hijau merupakan kemungkinan yang dinginkan konsumen untuk membeli produk yang ramah lingkungan (Chen \& Deng, 2016). Roe et al. (2001) mengatakan bahwa konsumen akan 
membeli produk hijau untuk melindungi atau tidak merusak lingkungan. Dalam literatur psikologi konsumen hijau, peneliti telah menemukan dengan suara bulat bahwa niat adalah prediktor mendasar perilaku pembelian (Wei et al., 2017).

\subsubsection{Sikap (Attitude)}

Ukuran sikap atas produk hijau dikonseptualisasikan sebagai keyakinan atau perasaan konsumen terhadap produk ramah lingkungan dan pengaruhnya terhadap lingkungan dalam hal kecenderungan yang menguntungkan dan tidak menguntungkan (Chen dan Chai, 2010). Barber et al., (2010) mengatakan bahwa sikap lingkungan merupakan faktor penjelas yang sangat baik tentang niat konsumen untuk membayar lebih produk hijau. Beberapa peneliti menyatakan bahwa sikap adalah prediktor yang lebih kuat dari niat dalam studi perilaku lingkungan, dan sikap atas produk hijau yang dimiliki konsumen secara positif akan mengarah pada tingkat tinggi niat beli produk hijau (Yadav dan Pathak, 2016). Oleh karena itu hipotesis dalam penelitian ini adalah:

$H_{1}$ : Sikap berpengaruh positif dan signifikan terhadap niat beli produk hijau

\subsubsection{Norma Subyektif (Subjective Norm)}

Norma subyektif dianggap sebagai komponen kedua pembentuk niat dalam model kognitif TPB. Norma subyektif adalah tekanan sosial yang dirasakan individu ketika melakukan perilaku tertentu (Ajzen, 1991). Tekanan sosial sebagian besar berasal dari sikap atau pendapat orang lain atau kelompok yang dianggap penting bagi orang tersebut, apakah orang tersebut harus melakukan perilaku tertentu (Park, 2000). Misalnya, ketika semakin banyak orang yang dianggap penting oleh seseorang setuju dengan perilaku tertentu, maka orang tersebut akan cenderung melakukan perilaku tertentu (Conner dan Armitage, 1998). Beberapa peneliti telah mengatakan bahwa norma subyektif merupakan faktor penting dari perilaku dalam bidang pemasaran dan penelitian konsumen seperti perilaku pembelian produk hijau (Jaiswal dan Singh, 2017); niat pembelian makanan halal Alam dan Sayuti (2011); dan niat pembelian makanan organik Urban et al., (2012). Studi yang telah dilakukan oleh beberapa peneliti menemukan hubungan secara positif dan signifikan antara norma subyektif dengan niat perilaku pembelian. Oleh karena itu hipotesis dalam penelitian ini adalah:

\section{$\mathrm{H}_{2}$ : Norma subyektif berpengaruh positif dan signifikan terhadap niat beli produk hijau}

\subsubsection{Kontrol Perilaku (Perceived Behavioral Control)}

Kontrol perilaku dipersepsikan sebagai penentu terpenting ketiga dalam model kognitif TPB. Kontrol perilaku adalah sejauh mana individu diharapkan untuk dapat mengendalikan perilaku tertentu (Ajzen, 1991). Kontrol perilaku mencerminkan kesulitan apakah seorang individu dapat menggunakan cara dan peluang tertentu untuk melakukan perilaku tertentu (Ajzen, 2005). Kontrol perilaku menjelaskan perilaku seperti daur ulang limbah dan perilaku konsumsi makanan organik (de Leeuw et al., 2014). Paul et al., (2016) mengatakan bahwa terdapat hubungan positif dan signifikan antara kontrol perilaku dengan niat perilaku pembelian produk 
hijau. Dalam penelitian ini, kontrol perilaku dianggap sebagai kemampuan konsumen untuk membeli produk organik. Ketika harga sebuah produk hijau khususnya pada produk organik sesuai dengan keterjangkauan ekonomi dan memiliki manfaat bagi kesehatan maka akan semakin berpengaruh positif pada niat perilaku pembelian terhadap produk hijau khususnya pada produk organik. Oleh karena itu hipotesis dalam penelitian ini adalah sebagai berikut:

$H_{3}:$ Kontrol perilaku berpengaruh positif dan signifikan terhadap niat beli produk hijau

\section{Metodologi Penelitian}

Jenis penelitian ini adalah penelitian kuantitatif yaitu dengan menyebarkan kuesioner kepada responden. Teknik pengambilan sampel yang digunakan adalah purposive sampling karena tidak memberikan peluang atau kesempatan sama bagi setiap unsur atau anggota populasi untuk dipilih menjadi sampel. Penyebaran kuesioner ditujukan langsung kepada seluruh konsumen yang mengkonsumsi produk pertanian organik di Sleman, Daerah Istimewa Yogyakarta. Kriteria responden dalam penelitian ini adalah individu yang terlibat di dalam proses pengambilan keputusan yaitu individu yang memiliki kecintaan terhadap lingkungan. Individu ini memiliki perilaku menjaga kelestarian lingkungan seperti mengelompokkan sampah berdasarkan jenisnya, mengurangi penggunaan plastik, mengkonsumsi produk yang aman bagi lingkungan.

\section{Hasil}

Responden dalam penelitian ini adalah konsumen yang melakukan pembelian produk pertanian organik. Kuesioner dibagikan kepada beberapa komunitas dan individu yang mengkonsumsi produk pertanian organik di Sleman, Daerah Istimewa Yogyakarta. Jumlah kuesioner yang dibagikan baik secara online maupun offline memiliki target diisi dan dikembalikan sebesar 200230 responden. Berdasarkan target tersebut, penelitian ini memperoleh jumlah responden sebanyak 228 responden. Daftar responden yang telah mengisi kuesioner ditunjukkan pada Tabel 2.

Metode analisis yang digunakan dalam penelitian ini adalah Partial Least Square (PLS). Teknik ini terdiri dari outer model atau measurement model, dan inner model atau structural model (Ghozali, 2014). Outer model atau uji indikator dilakukan untuk menilai reliabilitas dan validitas model. Hasil outer model pada penelitian ini ditunjukkan pada Tabel 3.

\section{Convergent Validity}

Nilai convergent validity adalah nilai outer loading pada variabel laten dengan indikatorindikatornya. Nilai outer loading antara $>0.7$ sudah dianggap sangat baik untuk memenuhi syarat convergent validity. Tabel 3 menunjukkan masing-masing indikator variabel memiliki nilai $>0.7$, sehingga semua indikator dinyatakan layak atau valid. 


\section{Composite Reliability}

Composite reliability merupakan bagian yang digunakan untuk menguji nilai reliabilitas indikator-indikator pada suatu variabel. Suatu variabel dapat dinyatakan memenuhi composite reliability apabila memiliki nilai composite reliability $>0.6$ (Ghozali, 2014). Berdasarkan sajian data pada tabel 3 di atas, dapat diketahui bahwa nilai composite reliability semua variabel penelitian $>0.6$, menunjukkan bahwa masing-masing variabel telah memenuhi composite reliability sehingga dapat disimpulkan bahwa keseluruhan variabel memiliki tingkat realibilitas yang tinggi.

\section{Tabel 1. Operasional Variabel Penelitian}

\begin{tabular}{|c|c|c|c|}
\hline Variabel & Definisi Operasional & Indikator & Sumber \\
\hline $\begin{array}{c}\text { Sikap atas } \\
\text { Produk Hijau } \\
\text { (SPH) }\end{array}$ & $\begin{array}{l}\text { Ukuran sikap atas produk hijau } \\
\text { dikonseptualisasikan sebagai keyakinan } \\
\text { atau perasaan konsumen terhadap } \\
\text { produk ramah lingkungan dan } \\
\text { pengaruhnya terhadap lingkungan dalam } \\
\text { hal kecenderungan yang menguntungkan } \\
\text { dan tidak menguntungkan (Chen \& } \\
\text { Chai, 2010). }\end{array}$ & $\begin{array}{ll}\text { a. } & \text { Menyukai ide pembelian } \\
\text { produk hijau. } \\
\text { b. } \\
\text { Memiliki sikap yang } \\
\text { menguntungkan terhadap } \\
\text { pembelian produk hijau. } \\
\text { c. } \begin{array}{l}\text { Pembelian produk hijau } \\
\text { adalah ide yang bagus. } \\
\text { d. }\end{array} \begin{array}{l}\text { Pembelian produk hijau } \\
\text { adalah pengalaman yang } \\
\text { menyenangkan. }\end{array} \\
\end{array}$ & $\begin{array}{l}\text { Paul et al., } \\
\text { (2016) } \\
\text { Kim dan } \\
\text { Han (2010) }\end{array}$ \\
\hline $\begin{array}{c}\text { Norma } \\
\text { Subyektif } \\
\text { (NS) }\end{array}$ & $\begin{array}{l}\text { Norma subyektif adalah tekanan sosial } \\
\text { yang dirasakan individu ketika } \\
\text { melakukan perilaku tertentu (Ajzen, } \\
\text { 1991). }\end{array}$ & $\begin{array}{ll}\text { a. } & \text { Orang yang dianggap } \\
\text { penting membeli produk } \\
\text { hijau. } \\
\text { b. } \\
\text { Merekomendasikan orang } \\
\text { yang dianggap penting } \\
\text { untuk membeli produk } \\
\text { hijau. }\end{array}$ & $\begin{array}{l}\text { Chan dan } \\
\text { Lau }(2000)\end{array}$ \\
\hline $\begin{array}{c}\text { Kontrol } \\
\text { Perilaku } \\
\text { (KP) }\end{array}$ & $\begin{array}{l}\text { Kontrol perilaku adalah sejauh mana } \\
\text { individu diharapkan untuk dapat } \\
\text { mengendalikan perilaku tertentu (Ajzen, } \\
\text { 1991). }\end{array}$ & $\begin{array}{l}\text { a. Membeli produk hijau } \\
\text { berdasarkan keinginan. } \\
\text { b. Memiliki sumber daya, } \\
\text { waktu dan kesempatan } \\
\text { untuk membeli produk } \\
\text { hijau. } \\
\text { c. Kamampuan untuk lebih } \\
\text { memilih produk hijau. }\end{array}$ & $\begin{array}{l}\text { Kim dan } \\
\text { Han (2010) }\end{array}$ \\
\hline $\begin{array}{c}\text { Niat Beli } \\
\text { Produk Hijau } \\
(\mathrm{NBH})\end{array}$ & $\begin{array}{l}\text { Niat pembelian produk hijau merujuk } \\
\text { pada kesiapan individu untuk melakukan } \\
\text { perilaku pembelian produk ramah } \\
\text { lingkungan, terutama mencerminkan } \\
\text { pertimbangan polusi yang lebih sedikit } \\
\text { (Chen \& Deng, 2016) }\end{array}$ & 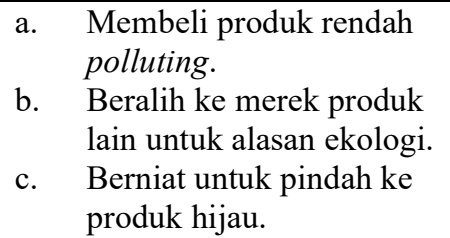 & $\begin{array}{l}\text { Chan dan } \\
\text { Lau (2000); } \\
\text { Mostafa } \\
(2006)\end{array}$ \\
\hline
\end{tabular}

\section{Average Variant Axtracted (AVE)}

Nilai average variant extracted (AVE) untuk masing-masing indikator dipersyaratkan nilainya harus $>0.5$ untuk model yang baik. Berdasarkan sajian data dalam tabel 3 di atas, diketahui 
bahwa nilai AVE masing-masing variabel memiliki nilai $>0.5$. Dengan demikian dapat dinyatakan bahwa setiap variabel telah memiliki validitas yang baik.

\begin{tabular}{lcc} 
Tabel 2. Profil Responden & & \\
\hline \multicolumn{1}{c}{ Keterangan } & Total & Presentase \\
\hline Jumlah sampel & $\mathbf{2 2 8}$ & $\mathbf{1 0 0 \%}$ \\
\hline Pekerjaan: & 23 & $10.1 \%$ \\
Pegawai (PNS/Swasta/dll) & 27 & $11.8 \%$ \\
Wirausaha & 121 & $53.1 \%$ \\
Ibu Rumah Tangga & 57 & $25.0 \%$ \\
Mahasiswa & & \\
\hline Tingkat Pendapatan: & 43 & $18.9 \%$ \\
< Rp. 1.000.000,- & 55 & $24.1 \%$ \\
Rp. 1.000.000,- s/d Rp. 3.000.000,- & 130 & $57.0 \%$ \\
> Rp. 3.000.000,- & & \\
\hline Merek/Nama Produk Organik: & 164 & $71.9 \%$ \\
Sayur & 44 & $19.3 \%$ \\
Buah & 20 & $8.8 \%$ \\
Beras & & \\
\hline Tempat Berbelanja: & 21 & $9.2 \%$ \\
Langsung ke Petani & 133 & $58.3 \%$ \\
Pasar/Warung Tradisional & 70 & $30.7 \%$ \\
Pasar Modern & 4 & $1.8 \%$ \\
Online & & \\
\hline Periode Waktu Belanja: & 137 & $60.1 \%$ \\
Harian & 53 & $23.2 \%$ \\
Setiap Minggu & 38 & $16.7 \%$ \\
Setiap Bulan & 24 & $10.5 \%$ \\
\hline Anggota Komunitas Produk Hijau: & 204 & $89.5 \%$ \\
Ya & &
\end{tabular}

Tabel 3. Construct Reliability and Validity

\begin{tabular}{|c|c|c|c|c|c|}
\hline Variabel & Indikator & $\begin{array}{l}\text { Outer } \\
\text { Loading }\end{array}$ & $\begin{array}{c}\text { Cronbach's } \\
\text { Alpha }\end{array}$ & $\begin{array}{l}\text { Composite } \\
\text { Reliability }\end{array}$ & $\begin{array}{c}\text { Average Variance } \\
\text { Extracted } \\
\text { (AVE) }\end{array}$ \\
\hline $\begin{array}{c}\text { Sikap atas Produk Hijau } \\
\text { (SPH) }\end{array}$ & $\begin{array}{l}\mathrm{SPH}_{1} \\
\mathrm{SPH}_{2} \\
\mathrm{SPH}_{3} \\
\mathrm{SPH}_{4} \\
\end{array}$ & $\begin{array}{l}0.881 \\
0.962 \\
0.914 \\
0.970 \\
\end{array}$ & 0.940 & 0.964 & 0.869 \\
\hline $\begin{array}{c}\text { Norma Subyektif } \\
\text { (NS) }\end{array}$ & $\begin{array}{l}\mathrm{NS}_{1} \\
\mathrm{NS}_{2}\end{array}$ & $\begin{array}{l}0.980 \\
0.980\end{array}$ & 0.959 & 0.980 & 0.961 \\
\hline $\begin{array}{c}\text { Kontrol Perilaku } \\
\text { (KP) }\end{array}$ & $\begin{array}{l}\mathrm{KP}_{1} \\
\mathrm{KP}_{2} \\
\mathrm{KP}_{3} \\
\end{array}$ & $\begin{array}{l}0.922 \\
0.945 \\
0.957 \\
\end{array}$ & 0.936 & 0.959 & 0.886 \\
\hline $\begin{array}{l}\text { Niat Beli Produk Hijau } \\
\text { (NBH) }\end{array}$ & $\begin{array}{l}\mathrm{NBH}_{1} \\
\mathrm{NBH}_{2} \\
\mathrm{NBH}_{3}\end{array}$ & $\begin{array}{l}0.960 \\
0.910 \\
0.942\end{array}$ & 0.970 & 0.977 & 0.894 \\
\hline
\end{tabular}




\section{Cronbach's Alpha}

Uji reliabilitas dengan composite reability di atas dapat diperkuat dengan menggunakan nilai cronbach's alpha. Suatu variabel dapat dinyatakan reliabel atau memenuhi cronbach's alpha apabila memiliki nilai cronbach's alpha $>0.7$ (Ghozali, 2014). Berdasarkan sajian data pada tabel 3, dapat diketahui bahwa nilai cronbach's alpha masing-masing variabel penelitian $>0.7$. Dengan demikian, hasil ini dapat menunjukkan bahwa masing-masing variabel penelitian telah memenuhi persyaratan nilai cronbach's alpha, sehingga dapat disimpulkan bahwa keseluruhan variabel memiliki tingkat reliabilitas yang tinggi.

\section{Discriminant Validity}

Suatu indikator dinyatakan memenuhi discriminant validity apabila nilai cross loading factor indikator pada variabelnya adalah yang paling besar dibandingkan pada variabel lainnya (Ghozali, 2014). Berdasarkan hasil yang diperoleh pada tabel 4, dapat dinyatakan, bahwa indikator-indikator yang digunakan dalam penelitian ini telah memiliki discriminant validity yang baik.

Tabel 4. Cross Loading Factor

\begin{tabular}{ccccc}
\hline Indikator & Sikap & Norma Subyektif & Kontrol Perilaku & Niat Beli \\
\hline $\mathbf{S P H}_{\mathbf{1}}$ & $\mathbf{0 . 8 8 1}$ & 0.812 & 0.846 & 0.834 \\
$\mathbf{S P H}_{\mathbf{2}}$ & $\mathbf{0 . 9 6 2}$ & 0.912 & 0.890 & 0.925 \\
$\mathbf{S P H}_{\mathbf{3}}$ & $\mathbf{0 . 9 1 4}$ & 0.868 & 0.884 & 0.848 \\
$\mathbf{S P H}_{\mathbf{4}}$ & $\mathbf{0 . 9 7 0}$ & 0.917 & 0.903 & 0.893 \\
\hline $\mathbf{N S}_{\mathbf{1}}$ & 0.925 & $\mathbf{0 . 9 8 0}$ & 0.912 & 0.928 \\
$\mathbf{N S}_{2}$ & 0.922 & $\mathbf{0 . 9 8 0}$ & 0.946 & 0.964 \\
\hline $\mathbf{K P}$ & 0.838 & 0.853 & $\mathbf{0 . 9 2 2}$ & 0.841 \\
$\mathbf{K} \mathbf{P}_{2}$ & 0.923 & 0.913 & $\mathbf{0 . 9 4 5}$ & 0.882 \\
$\mathbf{K P}_{3}$ & 0.905 & 0.909 & $\mathbf{0 . 9 5 7}$ & 0.929 \\
\hline $\mathbf{N B H}_{\mathbf{1}}$ & 0.906 & 0.937 & 0.927 & $\mathbf{0 . 9 6 0}$ \\
$\mathbf{N B H}_{\mathbf{2}}$ & 0.842 & 0.902 & 0.847 & $\mathbf{0 . 9 1 0}$ \\
$\mathbf{N B H}_{\mathbf{3}}$ & 0.873 & 0.875 & 0.862 & $\mathbf{0 . 9 4 2}$ \\
\hline
\end{tabular}

Tabel 5. Path Coefficients

\begin{tabular}{|c|c|c|c|c|c|c|}
\hline Hipotesis & $\begin{array}{c}\text { Original } \\
\text { Sample }\end{array}$ & $\begin{array}{c}\text { Sample } \\
\text { Mean }\end{array}$ & $\begin{array}{l}\text { Standard } \\
\text { Deviation }\end{array}$ & T Statistics & P-Value & Keterangan \\
\hline $\mathrm{SPH} \rightarrow \mathrm{NBH}$ & 0.804 & 0.803 & 0.055 & 14.487 & $0.000 * *$ & $\mathrm{H}_{1}$ : terbukti \\
\hline $\mathrm{NS} \rightarrow \mathrm{NBH}$ & 0.230 & 0.228 & 0.065 & 3.517 & $0.000 * *$ & $\mathrm{H}_{2}$ : terbukti \\
\hline $\mathrm{KP} \rightarrow \mathrm{NBH}$ & 0.350 & 0.352 & 0.103 & 3.397 & $0.001 *$ & $\mathrm{H}_{3}$ : terbukti \\
\hline
\end{tabular}


Pengujian hipotesis dilakukan dengan melihat nilai probabilitas yaitu 5\% dan t-statistik adalah 1.960. Pengujian hipotesis dengan Smart PLS dilakukan dengan cara melakukan proses bootstrapping, sehingga diperoleh hubungan pengaruh variabel eksogen terhadap variabel endogen pada tabel 5.

Berdasarkan hasil output pada tabel 5 diketahui pengujian hipotesis untuk masingmasing hubungan variabel laten menunjukkan bahwa ketiga hipotesis dalam penelitian ini memiliki pengaruh positif dan signifikan. Hasil uji pengaruh sikap atas produk hijau terhadap niat beli produk hijau menunjukkan nilai t-statistik $14.487>1.960$ dan $p$-value $0.000<0.05$. Nilai original sample estimate menunjukkan nilai positif sebesar 0.804 yang menunjukkan bahwa arah hubungan variabel sikap atas produk hijau terhadap variabel niat beli produk hijau adalah positif. Dengan demikian $\mathrm{H}_{1}$ pada penelitian ini diterima. Artinya, dalam penelitian ini variabel laten sikap atas produk hijau dengan indikator-indikatornya berpengaruh secara positif dan signifikan terhadap variabel laten niat beli produk hijau dengan indikator-indikatornya.

Uji pengaruh norma subyektif terhadap niat beli produk hijau menunjukkan nilai tstatistik $3.517>1.960$ dan $p$-value $0.000<0.05$. Nilai original sample estimate menunjukkan nilai positif sebesar 0.230 yang menunjukkan bahwa arah hubungan variabel norma subyektif terhadap variabel niat beli produk hijau adalah positif. Dengan demikian $\mathrm{H}_{2}$ pada penelitian ini diterima. Artinya, dalam penelitian ini variabel laten norma subyektif dengan indikatorindikatornya berpengaruh secara positif dan signifikan terhadap variabel laten niat beli produk hijau dengan indikator-indikatornya.

Uji pengaruh kontrol perilaku terhadap niat beli produk hijau menunjukkan nilai tstatistik $3.397>1.960$ dan $p$-value $0.000<0.05$. Nilai original sample estimate menunjukkan nilai positif sebesar 0.350 yang menunjukkan bahwa arah hubungan variabel kontrol perilaku terhadap variabel niat beli produk hijau adalah positif. Dengan demikian $\mathrm{H}_{2}$ pada penelitian ini diterima. Artinya, dalam penelitian ini variabel laten kontrol perilaku dengan indikatorindikatornya berpengaruh secara positif dan signifikan terhadap variabel laten niat beli produk hijau dengan indikator-indikatornya.

\section{Pembahasan dan Implikasi}

Penelitian ini mengacu pada theory of planned behavior yang telah dikemukakan oleh Ajzen yang menyusun model niat beli produk hijau, sikap, norma subyektif dan kontrol perilaku. Hasil uji pada penelitian ini telah membuktikan bahwa komponen sikap, norma subyektif dan kontrol perilaku berpengaruh terhadap niat beli produk organik.

Berdasarkan nilai perhitungan bootstrapping yang ditunjukkan oleh Tabel 5, maka diperoleh nilai 0.804 yang menunjukkan bahwa sikap atas produk hijau mempunyai pengaruh sangat signifikan terhadap niat beli produk hijau. Peneliti sebelumnya juga telah menemukan bahwa sikap atas produk hijau merupakan komponen yang paling signifikan dan berpengaruh terhadap niat beli produk hijau (Jaiswal dan Singh, 2017). Semakin tinggi sikap atas produk 
hijau yang dimiliki konsumen secara positif akan mengarah pada tingkat tinggi niat beli produk hijau (Yadav dan Pathak, 2016). Penelitian ini membuktikan bahwa sikap atas produk hijau memiliki hubungan signifikan terhadap niat beli produk hijau yang konsisten dengan penelitian Wei et al., (2017).

Komponen norma subyektif dalam penelitian ini memiliki pengaruh secara positif dan signifikan terhadap niat beli produk hijau. Hasil uji hipotesis dalam penelitian ini konsisten dengan penelitian terdahulu (Kim et al., 2013; Han, 2010). Namun, berdasarkan nilai perhitungan bootstrapping pengaruh norma subyektif terhadap niat beli produk hijau memiliki nilai lebih kecil dibanding pengaruh kontrol perilaku (0.350) terhadap niat beli produk hijau yaitu sebesar 0.230. Sebelumnya, penelitian terdahulu telah menyebutkan bahwa komponen norma subyektif memiliki peran yang lemah dalam model TPB (Sheppard et al., 1988; Conner dan Armitage, 2001). Guomin et al., (2019) mengatakan bahwa hal ini bergantung pada kondisi ekonomi dan sosial budaya pada daerah atau wilayah tertentu.

Dalam penelitian ini, daerah yang dipilih adalah Sleman yang merupakan kabupaten dengan pertumbuhan ekonomi yang paling maju dibandingkan kabupaten Daerah Istimewa Yogyakarta lainnya. Selain pertumbuhan ekonomi yang maju, daerah ini merupakan wilayah dimana universitas besar berada disini, sehingga bisa disebut bahwa mayoritas masyarakat daerah Sleman adalah orang-orang berpendidikan. Orang-orang dengan pendidikan tinggi cenderung memiliki norma-norma perilaku peduli pada lingkungan dan kesehatan, dan pada akhirnya akan mendorong untuk membeli produk hijau. Atmosfer yang berbeda menyebabkan perbedaan norma subyektif yang ada pada suatu masyarakat tertentu (Guomin et al., 2019). Oleh karena, itu penting untuk menciptakan atmosfer hijau terkhusus dalam hal praktik konsumsi produk hijau pada daerah yang masih tertinggal baik dari segi pertumbuhan ekonomi maupun pendidikan penduduknya.

Komponen kontrol perilaku dalam penelitian ini juga memiliki pengaruh secara positif dan signifikan terhadap niat beli produk hijau. Hasil uji hipotesis dalam penelitian ini konsisten dengan penelitian yang telah dilakukan oleh peneliti terdahulu (Chen dan Deng, 2016). Semakin tinggi kontrol perilaku yang dirasakan konsumen akan semakin mengarah pada niat beli produk hijau. Artinya bahwa ketika harga sebuah produk hijau sesuai dengan manfaat yang dirasakan, maka konsumen akan semakin memiliki niat beli terhadap produk hijau. Dengan kata lain harga tidak begitu penting bagi konsumen ketika sebuah produk hijau memiliki manfaat dan kualitas yang baik untuk kesehatan dan lingkungan.

Berdasarkan nilai perhitungan bootstrapping yang ditunjukkan oleh tabel 5, pengaruh kontrol perilaku terhadap niat beli produk hijau memiliki nilai lebih besar dibanding pengaruh norma subyektif $(0.230)$ terhadap niat beli produk hijau yaitu sebesar 0.350 . Hal ini menunjukkan bahwa kontrol perilaku memiliki pengaruh yang cukup besar terhadap niat beli produk organik. Para peneliti sebelumnya juga telah mengungkapkan bahwa kontrol perilaku adalah kontributor utama dalam mempengaruhi niat beli produk organik (Govindasamy et al., 
2010). Seorang individu mengendalikan perilakunya sendiri, oleh karena itu keputusan untuk membeli adalah hasil dari keyakinan individu itu sendiri (Ajzen, 2005).

Berdasarkan pemaparan hasil hipotesis di atas, diketahui bahwa konsumen bersedia mengkonsumsi produk organik. Secara garis besar dapat dikatakan bahwa keberlanjutan konsumsi tidak dapat dicapai tanpa menyeimbangkan permintaan dan penawaran sebagai dua sisi siklus bisnis yang harus seimbang. Di era persaingan bisnis modern, fenomena keberlanjutan bisnis tidak bisa dipisahkan dengan kepedulian atas keberlanjutan lingkungan. Di era industry 4.0 saat ini, pemasar harus mampu menghadapi tantangan dalam menyampaikan informasi kepada pasar yang memiliki norma budaya yang berbeda-beda. Pemasar dapat mempromosikan "green lifestyle" kepada masyarakat sehingga membentuk kesadaran untuk mengarah pada konsumsi yang berkelanjutan. Pada industri pertanian, kasus yang terjadi adalah konsumen tidak dapat membedakan antara produk organik dengan produk non-organik karena pemasar belum melakukan packaging atau pengemasan dengan baik dan benar. Sebagaimana produk hijau, pemasar harus menggunakan ecolabel yang mencerminkan bahwa produk tersebut adalah produk yang ramah bagi lingkungan. Selain memudahkan konsumen untuk lebih mengenali produk hijau, ecolabel sendiri dimaksudkan untuk membedakan produsen yang menerapkan proses hijau (Lin et al., 2015). Logo Green Mark yang dicetak pada label produk membantu konsumen mengenali perusahaan yang menerapkan proses produksi hijau (Administration, 2017). Selian itu perusahaan dan pemerintah dalam merealisasikan konsumsi berkelanjutan perlu lebih mempromosikan praktik green marketing dalam program penggunaan tas ramah lingkungan sehingga menghindari penggunaan plastik yang berlebihan serta pangemasan produk yang memakai label ecolabel dan lebih menekankan kampanye green marketing dalam menciptakan tuntutan berperilaku konsumsi produk hijau untuk alasan ekologi.

Dari segi harga, pemasar harus dapat memilih target pasar dengan tepat. Konsumen menengah ke atas adalah pasar yang tepat untuk produk organik yang termasuk ke dalam produk premium dengan harga yang lebih tinggi. Pemasar harus dapat memberikan kualitas yang baik untuk produk dengan harga yang premium, sehingga konsumen bersedia melakukan pembelian produk organik. Pengembangan produk juga penting untuk dapat mengikuti tren pasar yang semakin kompetitif.

Dengan menerapkan strategi pemasaran tersebut diharapkan tujuan ekonomi dalam sebuah perusahaan atau organisasi dapat dicapai dengan memenuhi permintaan konsumen akan produk organik. Selain memenuhi permintaan konsumen yang semakin sadar akan produk yang aman bagi kesehatan dan lingkungan juga mendorong masyarakat untuk ke arah konsumsi yang berkelanjutan. Oleh karena itu, keseimbangan dapat dipertahankan antara dunia bisnis yang semakin kompetitif dan pembangunan keberlanjutan dengan siklus bisnis (konsumsi dan produksi produk hijau) dalam konteks triple bottom line. 


\section{Keterbatasan dan Saran}

Penelitian ini memiliki beberapa keterbatasan yaitu: Pertama, sampel pada penelitian ini terbatas pada daerah tertentu yaitu Sleman, Daerah Istimewa Yogyakarta. Oleh karena itu, generalisasi dari model kognitif masih perlu diteliti lebih lanjut pada daerah lain. Perbedaan karakteristik dari masing-masing daerah, aspek budaya, demografi, infrastruktur dan ketersediaan produk antara daerah satu dengan yang lainnya memberikan kesempatan bagi peneliti selanjutnya untuk melakukan penelitian empiris pada konsumsi produk hijau di Indonesia. Kedua, meskipun penelitian ini membentuk model kognitif dari perilaku pembelian produk hijau yang konsisten dengan dasar teori yang digunakan, tetapi berdasarkan aspek teoritis, studi pada perilaku pembelian produk hijau masih memberikan peluang untuk menambahkan faktor lain sebagai anteseden model kognitif TPB, seperti perceived consumer effectiveness, perceived authority support, ecolabel, environmental concern, environmental knowledge, iklan produk hijau, kepercayaan produk hijau, dan sebagainya.

\section{Daftar Pustaka}

Administration, E.P. (2017). A Guide to Environmental \& Social Compliance, Textile Standards \& Legislation. Available online: https:// www.textilestandards.com/standards/76-taiwangreen-mark

Ajzen, I., \& Fishbein, M. (1980). Understanding attitudes and predicting social behavior Ajzen, I. (1991). (1991). The Theory of Planned Behavior. Organizational Behavior and Human Decision Processes, 50. 179-211.

Ajzen, I. (2001). Nature and Operation of Attitudes. Annual Review of Psychology, 52. pp 2758.

Ajzen, I. (2005). Laws of human behavior: Symmetry, Compatibility, and Attitude behavior Correspondence. In A. Beaudecul, B. Bicehl, M. Bosniak, W.Conrad, G. Schonberger, \& D.Wagener (Eds). Multivariate researchstrategies, 3-19. Aachen, Germany: Shaker Verla., 3-19.

Alam, S. S., \& Sayuti, N. M. (2011). Applying Theory Planned of Behavior (TPB) in Halal Food Purchasing. International Journal of Commerce and Management, 21(1). 8-20.

Barber, N., D. C. Taylor, dan S. Strick. (2010). Selective Marketing to Environmentally Concerned Wine Consumers: A Case For Location, Gender and Age. The Journal of Consumer Marketing, 27(1), 64-75.

Chan, R. Y. K., \& Lau, L.B.Y (2000), Antecedents of Green Purchases: A Survey in China, Journal of Consumer Marketing, Vol 17, No. 4. Pp 338-357.

Chen, K., Deng, T. (2016).Research on the Green Purchase Intentions from the Perspective of Product Knowledge. Sustainability, 8, 943.

Chen, T. B., Chai, L. T. (2010). Attitude towards the Environment and Green Products: Consumers' Perspective. Management Science and Engineering, 4 (2), 27-39.

Chen, Y. S., Chang, C. H. (2012). Enhance green purchase intentions: The roles of green perceived value, green perceived risk, and green trust. Manag.Decis.50, 502-520. 
Corner, M., Armitage, C. J. (1998). Extending the Theory Planned of Behavior: A Review and Avenues for Further Research. J. Appl. Soc. Psychol, 28. 1429-1464.

David, W. Ardiansyah. (2016). Organic agriculture in Indonesia: challenges and opportunities. Org.arg. doi: https://doi.org/doi:10.1007/s13165-016-0160-8.

de Leeuw, A., Valois, P., Seixas, R. (2014). Understanding High School Students' Attitude, Social Norm, Perceived Control and Beliefs to Develop Educational Interventions on Sustainable Development. In Proceedings of the $3^{\text {rd }}$ Cyprus International Conference on Educattional Research, Lefkosa, Cyprus, 30 January-1 February 2014; Uzunboylu, H., Ed.; Elsevier Science Bv: Amsterdam, The Netherlands, 2014; Volume 143, pp. 1200-1209.

Fishbein, M., \&Ajzen, I. (1975). Belief, attitude, intention and behavior: An introduction to theory and research. Menlo Park, California; Addison-Wesley Publishing Company Inc.

Ghozali, I. (2014). "Structural Equation Modeling-Metode Alternatif dengan Partial Least Squares (PLS)". Semarang: Universitas Diponegoro, 39.

Guomin, L., Wei, L., Zihan, j. Zhihao, W. (2019). Influence of Environmental Concern and Knowledge on Households' Willingness to Purchase Energy-Efficient Appliances: A Case Study in Shanxi, China. Sustainability, 11. 1073.

Govindasamy, R., Puduri, V., Simon, J. E. (2010). Hispanic consumers perceptions toward organically grown ethnic produce: A logistic analysis. Afr. J. Agric. Res, 5. 3464-3469.

Han, H. (2010). Intention to pay conventional-hotel prices at a green hotel- A modification of the theory of planned behavior AU-Kim, Yunhi. J. Sustain. Tour, 18. 997-1014.

Hubeis, M., Najib, M., Widyastuti, H., \& Wijaya, N. H. (2013). Farmer-based high value-added organic fodd production strategies. Journal Ilmu Pertanian Indonesia (JIPI). 18 (3): 194199.

Jaiswal, D., Singh, B. (2017). Toward sustainable consumption: Investigating the determinants of green buying behaviour of Indian consumers. Wiley Business Strategy and Development, $1-10$.

Kim, E., Ham, S., Yang, I. S., \& Choi, J. G. (2013). The roles of attitude, subjective norm, and perceived behavioral in the formation of consumers' nehavioral intentions to read menu labels in the restaurant industry. International Journal of Hospitality Management, 35. 203213.

Lin, S. C., Persada, S. F., Nadlifatin, R., Tsai, H. Y., Chu, C. H. (2015). Exploring the influential factors of manufacturers' initial intention in applying for the green mark ecolabel in taiwan. Int. J. Precis. Eng. Manuf. Green Technol, 2. 359-364.

Mostafa, M. M. (2006). Antecedents of Egyptian consumers' green purchase intentions: A hierarchical multivariate regression model. Journal of International Consumer Marketing, 19(2), 97-126.

Nugraheni, S. \& Purnama A. F. D. (2013). Problem and prospect of organic farming in Indonesia: lesson form five dstricts in West Java Province, $23^{\text {th }}$ Pasific Conference of the Regional Science Association International, July 2-4, 2013.

Paul, J., Modi, A., \& Patel, J. (2016). Predicting green product consumption using theory of planned behavior and reasoned action. Journal of Retailing and Consumer Services, 29, $123-134$.

Park, H. S. (2000). Relationships among attitudes and subjective norms: Testing the theory of reasoned action across cultures. Commun. Stud, 51. 162-175. 
Prasetyaningtyas, S. W., Maaruf, S., Sobir, R., Hermawan, A. (2019). Using Interpretive Structure Modelling in Developing an Organic Farming Sustainability Strategy in Indonesia. Journal of Agricultural Extension, 23(3). 196-207.

Rahab. Dharmmesta, B. S., Nugroho, S. S., Widyaningsih, Y. A., (2016). "Green Product Purchasing Phenomenon: Exploring the Gaps of Theoretical, Methodological and Empirical". Mimbar, 32(2), 372-381.

Robin, N., \& Roberts, S. (1998). Consumption in a sustainable world.[WWWdocument]. URL http:// www.iied.org/smg/pubs/work-bk2.html.

Roe, B., Teisl, M. F., Levy, A., Russell, M. (2001). US consumers' willingness to pay for green electricity. Energy Policy, 29, 917-925.

Sheppard, B. H., Hartwick, J., \& Warshaw, P. R. (1988). The theory of reasoned action: A metaanalysis of past researvh with recommendations for modifications and future research. Journal of consumer research, 15(3). 325-343.

Strauss, K. (2019). The Most Sustainable Companies In 2019. Forbes, https://www.forbes.com/sites/karstenstrauss/2019/01/22/the-most-sustainable-companiesin-2019/amp/?utm_source=TWITTER\&utm_medium=social\&utm_ term $=$ Malorie $\% 2 \mathrm{~F} \&$ twitter impression $=$ true

Sugiyono.(2013). Metode Penelitian Pendidikan (Pendekatan Kuantitatif, Kualitatif dan R\&D).Penerbit CV. Alfabeta: Bandung.

Tridjaja, N. O. (2016). Diversity of organic produce in Indonesia. Journal of Food Science an Engineering, 6(1).

Urban, J., Zverinova, I., Scasny, M. (2012). What Motivates Czech Consumers to Buy Organic Food? Czech Sociological Review, 4(1). 17-31.

Wei, C. F., Chiang, C. T., Kou, T. C., \& Lee, B. C. (2017). Toward sustainable livelihoods: Investigating the drivers of purchase behavior for green products. Business Strategy and the Environment, 26(5), 626-639.

Yadav, R., \& Pathak, G. S. (2016). Young consumers' intention towards buying green products in a developing nation: Extending the theory of planned behavior. Journal of Cleaner Production, 135, 732-739. 